\title{
Generic additions to the Rapateaceae of Rondônia, Brazil
}

\author{
Rodrigo Schütz RODRIGUES ${ }^{1 *}$ \\ 1 Universidade Federal de Roraima, Centro de Estudos da Biodiversidade, Av. Ene Garcez 2413, 69304-000, Boa Vista, RR, Brazil. \\ * Corresponding author: rodrigo.schutz@ufrr.br
}

\section{ABSTRACT}

Rapateaceae is a monocot family centered in the Guiana Shield region of South America. This article reports four generic additions to the Rapateaceae of Rondônia, a state in northern Brazil. Cephalostemon gracilis (Poepp. \& Endl.) R.H.Schomb., Duckea cyperaceoidea (Ducke) Maguire, Monotrema xyridoides Gleason, and Schoenocephalium cucullatum Maguire were recorded in lowland savannas and open white-sand ecosystems in the state. These findings extend significantly the known diversity of the Rapateaceae taxa occurring in Rondônia, and represent an extension of their geographical distribution to a Brazilian state with no part of its territory in the Guiana Shield.

KEYWORDS: Amazonia, floristics, Guiana Shield, new record

\section{Novos registros genéricos de Rapateaceae para Rondônia, Brasil}

\section{RESUMO}

Rapateaceae é uma família de monocotiledôneas centrada na regiáo do Escudo das Guianas da América do Sul. Este artigo relata o registro de quatro gêneros de Rapateaceae para o estado de Rondônia, norte do Brasil. Cephalostemon gracilis (Poepp. \& Endl.) R.H.Schomb., Duckea cyperaceoidea (Ducke) Maguire, Monotrema xyridoides Gleason e Schoenocephalium cucullatum Maguire são registrados em áreas de baixa altitude, ocorrendo em savanas e ecossistemas de campinas e campinaras no estado. Estas descobertas aumentam significativamente a diversidade conhecida de táxons de Rapateaceae para Rondônia, bem como representam uma extensão de sua distribuição geográfica para um estado que não tem nenhuma parte de seu território incluído no Escudo das Guianas.

PALAVRAS-CHAVE: Amazônia, Escudo das Guianas, florística, nova ocorrência 


\section{INTRODUCTION}

Rapateaceae Dumort. is a small angiosperm family belonging to the monocot Poales (APG IV 2016). The family comprises three subfamilies, Rapateoideae Maguire, Monotremoideae Givnish \& P.E. Berry and Saxofridericioideae Maguire, established on the basis of the ovule number, inflorescence bract and seed morphology (Givnish et al. 2004). Rapateaceae possesses 17 genera and 100 species occurring exclusively in the Neotropics, with the exception of Maschalocephalus dinklagei Gilg \& K.Schum., which is endemic of western Africa (Givnish et al. 2004; Berry 2004).

Rapateaceae probably arose in the Guiana Shield (Givnish et al. 2004), a northeastern region of South America between the Amazonas, Negro and Orinoco Rivers (Funk et al. 2007) markedly known by its high levels of plant endemism (Berry et al. 1995). In fact, with exception of six genera (Cephalostemon R.H.Schomb., Epidryos Maguire, Gilg \& K.Schum., Monotrema Körn., Rapatea Aubl., Spathanthus Desv. and Stegolepis Klotzsch ex Körn.), all remaining Neotropical genera of Rapateaceae are restricted to the Guiana Shield areas (Givnish et al. 2004; Berry 2004).

However, even though floristic works for Rapateaceae are available for Venezuela, Colombia and the Guianas (Maguire 1958; 1965; 1982; Boom 1997; Berry 2004; 2008; Funk et al. 2007; Aymard and Arellano-Peńa 2016; Rodrigues and Flores 2017), studies in adjacent areas in Brazil are relatively scarce (Maguire 1979; Forzza and Costa 2005; Rodrigues and Flores 2010; Rodrigues 2015; Barbosa-Silva et al. 2016; Praia et al. 2016). The knowledge about the biodiversity of the state of Rondônia is still incomplete (Carleial and Bigio 2014), including its rapateacean flora. Only four species of Rapatea have been reported in the literature for Rondônia (BFG 2015), which places Rondônia as the northern Brazilian state with the lowest richness of genera and species of Rapataceae, after the state of Acre (BFG 2015).

This article reports generic additions of Rapateaceae to Rondônia, providing a description and information on the previously known geographical distribution for each taxon. An updated inventory of Rapateaceae of Rondônia is discussed on a regional scale, taking into consideration the limits of the Guiana Shield in northern Brazil.

\section{MATERIALS AND METHODS}

I primarily analyzed specimens of Rapateaceae from Rondônia state included in the UFRR herbarium (acronym according to Thiers 2017), with emphasis on duplicates collected in 2013 and 2014 in the Campos Amazônicos National Park (CANP) and adjacent areas. The CANP has an area of $809,158 \mathrm{ha}$ and is located between the coordinates of $7^{\circ} 30^{\prime} \mathrm{S}$ to $9^{\circ} 15^{\prime} \mathrm{S}$, and $61^{\circ} 30^{\prime} \mathrm{W}$ to $62^{\circ} 30^{\prime} \mathrm{W}$ (Figure 1),

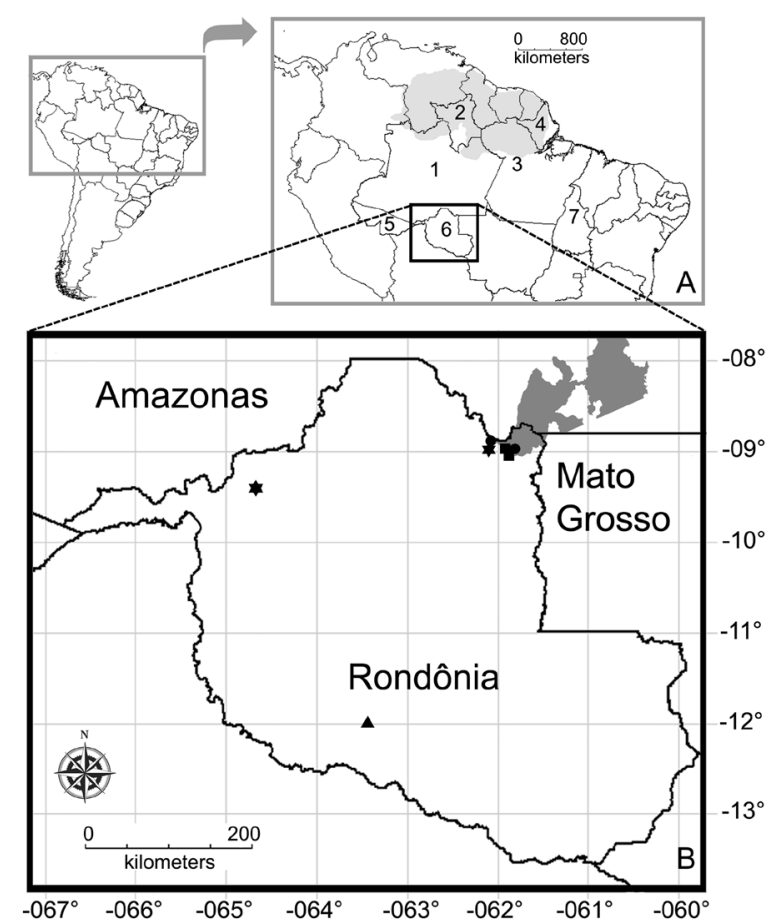

Figure 1. Geographical distribution of novel occurrences of Rapateaceae in Rondônia state, Brazil. A. Maps of South America and adjacent Central America, numbering the states of northern Brazil: 1 (Amazonas), 2 (Roraima), 3 (Pará), 4 (Amapá), 5 (Acre), 6 (Rondônia) and 7 (Tocantins); the shaded area corresponds to the Guiana Shield limits according to Funk et al. (2007). B. Cephalostemon gracilis (Poepp. \& Endl.) R.H.Schomb. (triangle), Duckea cyperaceoidea (Ducke) Maguire (stars), Monotrema xyridoides Gleason (circles) and Schoenocephalium cucullatum Maguire (squares) occurrences in and around the Campos Amazônicos National Park (shaded area) and other areas in Rondônia.

extending mainly over lowland areas (ca. 100-250 m altitude) in the states of Rondônia, Amazonas, and Mato Grosso (D'Amico and Coutinho 2011). The CANP is biologically important, for it protects a part of the largest area of the savanna-like Cerrado in southern Amazonia along its contact with white-sand forests (campinaranas) and other forest formations, and also an important river system (D'Amico and Coutinho 2011).

Additionally, available images of specimens from Rondônia in CEN, HUEFS, INPA, NY, RB, RON and UEC herbaria (acronyms according to Thiers 2017) were consulted, mainly by means of the speciesLink network (2017) and Reflora Virtual Herbarium (2017) online resources. When available, selected specimens from neighbor states were also analyzed, but descriptions were based only on the material examined from Rondônia. Specimens were identified using specialized literature (Gleason 1931; Maguire 1958; 1965; 1982; Berry 2004). Maps were produced using DIVA-GIS 
software (Hijmans et al. 2012). The limits of the Guiana Shield (Figure 1A) were extracted from Funk et al. (2007).

\section{RESULTS}

The analysis of Rapateaceae specimens at UFRR and additional herbaria revealed the occurrence of Cephalostemon gracilis (Poepp. \& Endl.) R.H.Schomb., Duckea cyperaceoidea (Ducke) Maguire, Monotrema xyridoides Gleason, and Schoenocephalium cucullatum Maguire in the state of Rondônia (Figures 1 and 2). Below I present a brief account on the examined material from Rondônia.

Cephalostemon gracilis (Poepp. \& Endl.) R.H.Schomb. (Schomburgk 1845). Figures 1B and 2A-B.

Description: Terrestrial herbs. Leaf sheaths 9.5-11 x 0.9-1.1 cm, blades 50-62 x 0.3-0.4 cm, linear, 9-11-veined, abaxially with the midvein conspicuously prominent. Inflorescence peduncle erect, $50-60 \mathrm{~cm}$ long, $1.5-1.8 \mathrm{~mm}$ wide, widening to $3 \mathrm{~mm}$ at the top. Inflorescence subglobose, 20-27 mm in diameter; bracts $2,30-40 \times 1.5-3 \mathrm{~mm}$, linearlanceolate. Spikelets 8-10, 10-12 mm long; external bracteoles 4-5 mm long, nerved, acuminate, the internal ones 10-11 $\mathrm{mm}$ long, setose and clavate at apex. Sepals 9.5-11 mm long; petals and anthers not seen.

Distribution: Brazil (Amazonas, Amapá, Pará, Mato Grosso) (Maguire 1958; BFG 2015; Praia et al. 2016).

Material examined: Brazil. Rondônia: Costa Marques, W of river Cautarinho, $6 \mathrm{~km}, \mathrm{~N}$ of highway BR 429, 1201'S, 6327’W, 25/III/1987, M.H. Nee 34487 (INPA, UFRR).

Additional material examined: Brazil. Amazonas: Manicoré, BR-230, Transamazônica highway, $243 \mathrm{~km}$ from Humaitá, 24/IV/1985, C.A.C. Ferreira et al. 5794 (INPA, NY). Aripuanã, BR-230, Transamazônica highway between Km 350 and 400 east from Humaitá, Ferreira, 30/IV/1985, C.A.C. Ferreira et al. 5911 (INPA, NY).

Duckea cyperaceoidea (Ducke) Maguire (Maguire 1958). Figures 1B, 2C-D.

Description: Terrestrial herbs. Leaf sheaths 6-12 x 0.5-0.6 $\mathrm{cm}$, blades 30-100 x 0.4-0.5 cm, linear, 9-veined, with the midvein conspicuously abaxially prominent. Inflorescence peduncle erect, $30-75 \mathrm{~cm}$ long, $1.5-2 \mathrm{~mm}$ wide, widening to $4 \mathrm{~mm}$ at the top. Inflorescence globose, $12-19 \mathrm{~mm}$ in diameter; bracts 2, 90-150 x 4-5 mm, linear-lanceolate. Spikelets 35-45, 6.8-7.5 mm long; external bracteoles 4-5 $\mathrm{mm}$ long, inconspicuously nerved, the internal ones $5-6 \mathrm{~mm}$ long, long acuminate at apex (acumen $>3 \mathrm{~mm}$ long). Sepals 5-6 mm long; petals 3-3.5 mm long; anthers 2.5-2.7 mm long, without apical appendices.

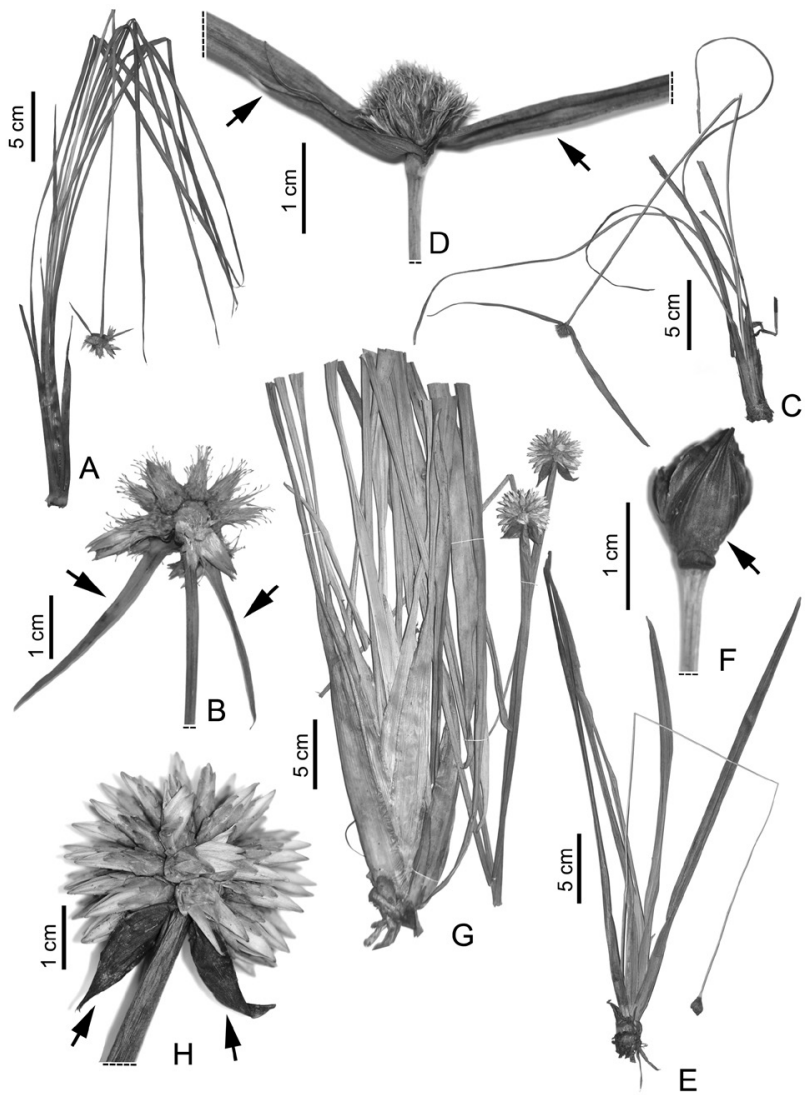

Figure 2. Novel occurrences of Rapateaceae in Rondônia state, Brazil. A-B. Cephalostemon gracilis (Poepp. \& Endl.) R.H.Schomb. A. Habit. B. Distal part of the peduncle and the two adjacent bracts (arrows) subtending a subglobose inflorescence. C-D. Duckea cyperaceoidea (Ducke) Maguire. C. Habit. D. Distal part of the peduncle and the two adjacent bracts (arrows) subtending a globose inflorescence. E-F. Monotrema xyridoides Gleason. E. Habit. F. Distal part of the peduncle of an inflorescence with numerous spikelets, indicating the outermost inflorescence bract (arrow). G-H. Schoenocephalium cucullatum Maguire. G. Habit. H. Distal part of the peduncle and the two adjacent bracts (arrows) of an inflorescence with numerous spikelets. (A-B: Nee 34487; C-D: Sandrini \& Resende s.n., UFRR 8642; E-F: Capistrano et al. 115; G-H: Capistrano et al. 44).

Distribution: Venezuela (Amazonas), Colombia (Guainía), and Brazil (Amazonas, Pará, Roraima) (Maguire 1958; 1982; Berry 2004; 2008; BFG 2015, Praia et al. 2016).

Material examined: Brazil. Rondônia: Machadinho d'Oeste, left margin of the Ji-Paraná River, near the District of Tabajara, 8055'38"S, 62005'06"W, 17/II/2014, M. Sandrini \&T. Resende s.n. (UFRR 8641). Ib., M. Sandrini \& T. Resende s.n. (UFRR 8642). Porto Velho, south of Mutum Paraná, 9०22'42"S, 64040'41"W, 24/X/2010, G. Pereira-Silva et al. 15756 (CEN, HUEFS, INPA, RB, RON).

Additional material examined: Brazil. Amazonas: Apuí, Nova Prainha, ca. $13 \mathrm{~km}$ on road to Prainha N. of Transamazônica highway, 25/VI/1979, C.E. Calderón et al. 
2670 (INPA). Humaitá, Estanho road, between Km 795 and 790 of Transamazônica highway, 26/04/1979, G. Vieira et al. 182 (INPA).

Monotrema xyridoides Gleason (Gleason 1931). Figures 1B, 2E-F.

Description: Terrestrial herbs. Leaf sheaths $7-8 \times 0.8-1 \mathrm{~cm}$, blades 18-25 x 0.6-1 cm, linear, 11-15-veined, with the midvein conspicuously abaxially prominent. Inflorescence peduncle erect, $45-48 \mathrm{~cm}$ long, $1.2-1.5 \mathrm{~mm}$ wide, widening to $4 \mathrm{~mm}$ at the top. Inflorescence globose, 9-10 $\mathrm{mm}$ in diameter; bracts numerous, the outermost $10-12 \times 7-8 \mathrm{~mm}$, widely lanceolate. Spikelets 15-20, 7.8-8.3 mm long; external bracteoles 5.8-6.5 $\mathrm{mm}$ long, 3-5-nerved, the internal ones 5-6 $\mathrm{mm}$ long, obtuse at apex. Sepals 6.8-7.5 $\mathrm{mm}$ long; petals 7-7.5 $\mathrm{mm}$ long; anthers 2.4-2.7 mm long, without apical appendices.

Distribution: Venezuela (Amazonas), Colombia (Caquetá, Guainía, Vaupés), and Brazil (Amazonas, Roraima) (Maguire 1958; 1982; Berry 2004; 2008; BFG 2015).

Material examined: Brazil. Rondônia: Machadinho d'Oeste, Tabajara village, 8050'45”S , 6204'52”W, fl., VIII/2013, T.R.C. Capistrano et al. 35 (UFRR 8583); Ib., 8058'47"S, 61053'44”W, fl., II/2014, T.R.C. Capistrano et al. 115 (UFRR 8643).

Additional material examined: Brazil. Amazonas: Humaitá, BR-230 Transamazônica highway, $150 \mathrm{Km}$ from Humaitá on Estanho road, $40 \mathrm{Km}$ on this road, 21/IV/1985, A.J. Henderson et al. 294 (INPA). Ib., $32 \mathrm{~km} \mathrm{~S}$ of Transamazon highway (150 km E of Humaitá), Estanho road, 27/IX/1979, J.L. Zarucchi et al. 2599 (INPA, UEC).

Schoenocephalium cucullatum Maguire (Maguire 1958). Figures 1B, 2G-H.

Description: Terrestrial herbs. Leaf sheaths $15-18 \times 1.9-$ $2.5 \mathrm{~cm}$, blades $25-35 \times 1.5-2 \mathrm{~cm}$, linear, 8-10-veined, with midvein inconspicuous. Inflorescence peduncle erect, 95-100 $\mathrm{cm}$ long, 4.8-5.3 $\mathrm{mm}$ wide, widening to $10 \mathrm{~mm}$ at the top. Inflorescence globose, 34-37 $\mathrm{mm}$ in diameter; bracts 2, 15$20 \times 13-16 \mathrm{~mm}$, widely lanceolate, reflexed. Spikelets $28-45$, 15.2-16.3 mm long; external bracteoles 2.7-4.5 mm long, 3-5-nerved, the internal ones 8-14.3 mm long, obtuse and cucullate. Sepals 14-15 mm long; petals 10-12 mm long; anthers 3-4.5 mm long, without apical appendices.

Distribution: Venezuela (Amazonas), Colombia (Guainía), and Brazil (Amazonas) (Maguire 1958; 1982; Berry 2004; 2008; BFG 2015).

Material examined: Brazil. Rondônia: Machadinho d'Oeste, left margin of the Ji-Paraná River, 8०58'44"S, 61053'41"W, fl., 17/II/2014, M. Sandrini \& T. Resende s.n. (UFRR 8644). Ib., Tabajara village, 8058,39»S, 61053,46»W, fl., II/2014, T.R.C. Capistrano et al. 44 (UFRR 8582).
Additional material examined: Brazil. Amazonas: Apuí, Nova Prainha, Project RADAM/ BRASIL, SB-20-ZBPto. O7, 22/VII/1976, C.D.A Mota \& O.P. Monteiro s.n. (INPA 60659). Manicoré: Igarapé Preto, $60 \mathrm{Km}$ SE from Transamazônica highway, 02/VII/1979, C.E. Calderón et al. $2747(\mathrm{NY})$.

\section{DISCUSSION}

Literature data (Maguire 1958; Berry 2004; BFG 2015) coupled with the present report show that an updated inventory of Rapateaceae of Rondônia contains five genera and eight species (Table 1). The results indicate that Rondônia is, together with Pará state, now the third state in northern Brazil with the highest number of genera and species of Rapateaceae, only behind the states of Amazonas and Roraima (Table 1). Rapatea, with four recorded species, can be distinguished from the four genera here added to Rondônia’s flora by presenting two relatively large bracts subtending the inflorescence and anthers with an apical hooded appendage (Berry 2004).

Cephalostemon possesses five species distributed from northern South America to southeastern Brazil and Bolivia (Berry 2004). All species of Cephalostemon have been recorded in Brazil, in the states of Amazonas, Amapá, Goiás, Mato Grosso, Mato Grosso do Sul, Minas Gerais, Pará and Tocantins (Berry 2004; BFG 2015). The specimen analyzed from Rondônia has inflorescences with numerous spikelets, whose external bracteoles are acuminate and the internal ones setose and clavate at the apex. This description agrees with the traits observed in Cephalostemon gracilis (Maguire 1958; Praia et al. 2016). In Rondônia, this species occurred in sandy and periodically wet savannas with scattered palms and shrubs, but it has been found elsewhere in seasonally flooded white-sand savannas (Praia et al. 2016).

Duckea has four species distributed in northern South America (Berry 2004). In Brazil, three species have been recorded, in the states of Amazonas, Pará and Roraima (BFG 2015). Duckea cyperaceoidea is most similar to D. squarrosa, but it differs by having inflorescences up to $20 \mathrm{~mm}$ in diameter (vs. inflorescences $20>\mathrm{mm}$ in diameter), bracteoles with long acuminate apex (vs. acute or acuminate apex), the external ones inconspicuously veined (vs. strongly nerved) (Maguire 1982; Berry 2004). In Rondônia, D. cyperaceoidea occurred in shrubby white-sand savannas, but elsewhere it has been recorded on forest edges, open white-sand savannas, and edges of rocky outcrops (Berry 2004).

Monotrema has four species and an interspecific hybrid, distributed in southern Venezuela and adjacent regions of Colombia and Brazil (Berry 2004). In Brazil, BFG (2015) recorded two species, M. aemulans Körn. and M. xyridoides, from the states of Amazonas, Mato Grosso and Roraima. However, Rodrigues (2015) additionally confirmed the 
Table 1. Taxa of Rapateaceae recorded for northern Brazil states based on (a) Rodrigues and Flores (2010); (b) Rodrigues (2015); (c) BFG (2015); (d) Costa et al. (2016); (e) Barbosa-Silva et al. (2016); (f) Praia et al. (2016); (g) present work. Acronyms for Brazilian states: (AC) Acre; (AM) Amazonas; (AP) Amapá; (PA) Pará; (RO) Rondônia; (RR) Roraima; (TO) Tocantins. Bold:present data. Guianan and extra-Guianan respectively refer to those northern Brazil states included or not in the Guiana Shield limits according to Funk et al. (2007).

\begin{tabular}{|c|c|c|c|c|c|c|c|c|}
\hline \multirow{2}{*}{ Taxa/number of species } & \multicolumn{4}{|c|}{ Guianan } & \multicolumn{3}{|c|}{ Extra-Guianan } & \multirow{2}{*}{ Source } \\
\hline & AM & $\mathrm{RR}$ & PA & $\mathrm{AP}$ & $A C$ & R0 & TO & \\
\hline \multicolumn{9}{|l|}{ Subfam. Rapateoideae } \\
\hline Cephalostemon & 3 & 1 & 1 & 1 & - & 1 & 3 & $c, f$ \\
\hline Duckea & 3 & 2 & 1 & - & - & 1 & - & $c, d, f, g$ \\
\hline Rapatea & 10 & 1 & 4 & 2 & 3 & 4 & 2 & $a, c, f$ \\
\hline Spathanthus & 2 & 1 & 1 & 2 & - & - & - & $c, f$ \\
\hline \multicolumn{9}{|l|}{ Subfam. Monotremoideae } \\
\hline Monotrema & 2 & 3 & - & - & - & 1 & - & $b, c, d, g$ \\
\hline \multicolumn{9}{|c|}{ Subfam. Saxofridericioideae } \\
\hline Epidryos & - & 1 & - & - & - & - & - & $\mathrm{a}, \mathrm{c}$ \\
\hline Saxofridericia & 5 & 2 & 1 & 1 & - & - & & $c, f$ \\
\hline Schoenocephalium & 1 & - & - & - & - & 1 & & $\mathrm{C}, \mathrm{g}$ \\
\hline Stegolepis & 3 & 4 & - & - & - & - & - & $\mathrm{a}, \mathrm{c}, \mathrm{e}$ \\
\hline Total: genera (species) & $8(29)$ & $8(15)$ & $5(8)$ & $4(6)$ & $1(3)$ & $5(8)$ & $2(5)$ & \\
\hline
\end{tabular}

occurrence of $M$. bracteatum Maguire in Brazil, for the state of Roraima. Monotrema xyridoides is similar to M. aemulans, as both have the outermost bracts shorter to slightly longer than the inflorescences (Maguire 1982; Berry 2004). The ovoid inflorescences, with up to 25 spikelets and obtuse bracteoles observed in Rondonian specimens agree with M.xyridoides, in opposition to the nearly hemispheric inflorescences, with 40 to 75 spikelets, and subacute and apiculate bracteoles found in M. aemulans (Maguire 1982; Berry 2004). In Rondônia, $M$. xyridoides occurred in open or shrubby savannas, but it has been found elsewhere in open moist white-sand savannas (Berry 2004).

Schoenocephalium comprises four species, distributed in Colombia, Venezuela, and Brazil (Berry 2004). BFG (2015) recorded two species for Brazil in the states of Amazonas and Mato Grosso. The examined material of Schoenocephalium from Rondônia possesses sepals exceeding the tips of the upper bracteoles 1-3 mm and plane leaf blades. This character set is shared by two close species, $S$. cucullatum and $S$. schultesii Maguire. As the analyzed specimens have the upper bracteoles cucullate, inflorescences with up to 45 spikelets, and 2(-3) ovules per locule, they correspond to $S$. cucullatum (Maguire 1958; 1982; Berry 2004). On the other hand, S. schultesii differs by having the upper bracteoles not cucullate, inflorescences with 60 to 80 spikelets, and 4 ovules per locule (Maguire 1958; 1982). In Rondônia, S. cucullatum occurred in shrubby savannas, but has been found elsewhere in seasonally flooded white-sand savannas (Berry 2004).
An analysis of available specimens in both speciesLink network (2017) and Reflora Virtual Herbarium (2017) indicated that a previously putative record of Cephalostemon in Rondônia (Pereira-Silva et al. 15756) corresponds indeed to Duckea cyperaceoidea. However, in these two online databases there are Rondonian specimens of Cephalostemon (e.g., G.T. Prance et al. 5833; C.D. Mota \& D. Cô̂lho 190) whose identifications need to be further confirmed. Species delimitation in Cephalostemon is intricate, as four species are morphologically very similar and possibly diagnosed by variable characters (Pirani and Giulietti 1989; Berry 2004; Praia et al. 2016). Cephalostemon gracilis is the older name in the genus and is probably conspecific with $C$. affinis Körn. (Praia et al. 2016), also forming a species complex with $C$. angustatus Malme and C. riedelianus Körn (Berry 2004).

On a regional scale, only four states in northern Brazil have variable proportions of their territory in the Guiana Shield area: Amazonas, Roraima, Pará, and Amapá (Figure 1A). The rapateacean flora of these four states is relatively rich, possessing all the nine genera and 36 from the 40 species recorded for Brazil (Rodrigues and Flores 2010; BFG 2015; Rodrigues 2015; Barbosa-Silva et al. 2016). On the other hand, for the entirely extra-Guianan states of northern Brazil (Acre, Rondônia, and Tocantins; Fig. 1B) only eight species of Cephalostemon and Rapatea had been recorded so far (BFG 2015). 
With the records reported herein, the rapateacean flora of northern Brazilian extra-Guianan states currently comprises five genera and 12 species of the three subfamilies (Table 1). It is interesting to note that, with exception of Schoenocephalium, all these taxa belong to distinct, predominantly lowland lineages of Rapateaceae subfamilies Rapateoideae (Duckea, Rapatea, Cephalostemon) and Monotremoideae (Monotrema) (Givnish et al. 2004). On the other hand, Schoenocephalium, though belonging to a preponderantly upland or highland subfamily (Saxofridericioideae), is a lowland genus which is included in a small lineage that probably shifted back to low altitudes (Givnish et al. 2004).

In this respect, the occurrence of Cephalostemon gracilis, Duckea cyperaceoidea, Monotrema xyridoides and Schoenocephalium cucullatum in lowland savannas and open white-sand ecosystems at the CANP agrees with the similar altitudinal and habitat preferences previously documented for these species in Guiana Shield areas (Berry 2004) and in some municipalities of the Amazonas state close to the border with Rondônia. These results suggest that the four species may be more widespread in other extra-Guianan areas in northern Brazil, since García-Villacorta et al. (2016) observed that long-distance dispersal events are important to link white-sand floras from Guiana Shield and Amazonian areas. A better understanding of the biogeography of Rapateaceae in Amazonia still depends on the expansion of collections at sites still unexplored. In this regard, Milliken $e t$ al. (2010) and Zappi et al. (2016) have already emphasized that the poor knowledge of species distribution patterns, especially in northern Brazil, is a result of the pronounced incompleteness of floristic knowledge in this region. Since other recent additions to Rapateaceae from northern Brazil were from both lowland (Rodrigues 2015; Costa et al. 2016) and mountain areas (Rodrigues and Flores 2010; BarbosaSilva et al. 2016), additional collection efforts must consider the distinct elevation preferences of taxa within this family.

\section{CONCLUSIONS}

As reported herein, Cephalostemon gracilis, Duckea cyperaceoidea, Monotrema xyridoides and Schoenocephalium cucullatum Maguire are new records for the state of Rondônia. The documented occurrence of species of Duckea, Cephalostemon Monotrema and Schoenocephalium extends significantly the known diversity of the Rapateaceae taxa occurring in this state, that has no part of its territory in the Guiana Shield.

\section{ACKNOWLEDGMENTS}

I thank Dr. Andréia Silva Flores for reading early versions of this manuscript; Marcos Paulo Sandrini (JGP Consultoria e Participaçôes) for providing botanical material. Dr. Rafael
Boldrini kindly helped me with the preparation of some plant images. Dr. Michael Hopkins generously sent me Rapateaceae material from the Instituto Nacional de Pesquisas da Amazônia herbarium. Staff at both Museu Integrado de Roraima and Universidade Federal de Roraima herbaria are thanked for supporting this study. I gratefully acknowledge anonymous reviewers and editor Dr. Claudia Keller for their valuable reviews.

\section{REFERENCES}

APG IV (The Angiosperm Phylogeny Group). 2016. An update of the Angiosperm Phylogeny Group classification for the orders and families of flowering plants: APG IV. Botanical Journal of the Linnean Society, 181: 1-20.

Aymard, G.; Arellano-Peña, H. 2016. Novelties in Rapatea (Rapateaceae) from Colombia. Revista de la Academia Colombiana de Ciencias Exactas, Físicas y Naturales, 40: 644-652.

Barbosa-Silva, R.G.; Labiak, P.H.; Gil, A.S.B.; Goldenberg, R.; Michelangeli, F.A.; Martinelli, G.; Coelho, M.A.N.; Zappi, D.C.; Forzza, R.C. 2016. Over the hills and far away: New plant records for the Guayana Shield in Brazil. Brittonia, 68: 397-408.

Berry, P.E. 2004. Rapateaceae. In: Berry, P.E.; Yatskievych, K.; Holst, B.K. (Ed.). Flora of the Venezuelan Guayana. v.8. Missouri Botanical Garden Press, St. Louis, p. 413-472.

Berry, P.E. 2008. Rapateaceae. In: Hokche, O.; Berry, P.E.; Huber, O. (Ed.). Nuevo Catálogo de las Plantas Vasculares de Venezuela. Herbario Nacional de Venezuela, Caracas, p. 819-821.

Berry, P.E.; Huber, O.; Holst, B.K. 1995. Floristic analysis and phytogeography. In: Berry, P.E.; Holst, B.K.; Yatskievych, K. (Ed.). Flora of the Venezuelan Guayana. v.1. Missouri Botanical Garden Press, St. Louis, p. 161-191.

BFG (The Brazil Flora Group). 2015. Growing knowledge: An overview of seed plant diversity in Brazil. Rodriguésia, 55: 1085-1113.

Boom, B.M. 1997. Rapateaceae. In: S. A. Mori, S.A.; Cremers, G.; Gracie, C.; Granville, J.J.; Hoff, M.; Mitchell, J.D. (Ed.). Guide to the vascular plants of central French Guiana. Memoirs of The New York Botanical Garden 76: 360-364.

Carleial, S.; Bigio, N.C. 2014. What survived from the PLANAFLORO Project: Angiosperms of Rondônia State, Brazil. Check List, 10: 33-45.

Costa, S.M.; Barbosa, T.D.M.; Bittrich, V.; Amaral, M.C.E. 2016. Floristic survey of herbaceous and subshrubby aquatic and palustrine angiosperms of Viruá National Park, Roraima, Brazil. PhytoKeys, 58: 21-48.

D’Amico, A.R.; Coutinho, E.O. (Ed.). 2011. Plano de Manejo - Parque Nacional dos Campos Amazônicos. Instituto Chico Mendes de Conservação da Biodiversidade, Brasília, 346p. (http://www.icmbio.gov.br/portal/images/stories/docs-planosde-manejo/parna_campos_amazonicos_pm.pdf). Accessed on $15 / 06 / 2016$.

Forzza, R.C.; Costa, M.A.S. 2005. Flora da Reserva Ducke, Amazonas, Brasil: Rapateaceae. Rodriguésia, 56: 177-181. 
Funk, V.; Hollowell, T.; Berry, P.; Kelloff, C.; Alexander, N.S. 2007. Checklist of the plants of the Guiana Shield (Venezuela: Amazonas, Bolivar, Delta Amacuro; Guyana, Surinam, French Guiana). Contributions from the United States National Herbarium, 55: 1-584.

García-Villacorta, R.; Dexter, K.G.; Pennington, T. 2016. Amazonian white-sand forests show strong floristic links with surrounding oligotrophic habitats and the Guiana Shield. Biotropica, 48: 47-57.

Givnish, T.J., Millam, K.C.; Evans, T. M.; Hall, J.C.; Pires, J.C.; Berry, P.E.; Sytsma, K.J. 2004. Ancient vicariance or recent long-distance dispersal? Inferences about phylogeny and South American-African disjunctions in Rapateaceae and Bromeliaceae based on ndhF sequence data. International Journal of Plant Sciences, 165: S35-S54.

Gleason, H.A. 1931. Botanical Results of the Tyler-Duida Expedition. Bulletin of the Torrey Botanical Club, 58: 277-344.

Hijmans R.J.; Guarino, L.; Mathur, P. 2012. DIVA-GIS manual. University of California Davis, Version 7.5 (http://www.diva-gis. org/). Accessed on 06/06/2016.

Maguire, B. 1958. Rapateaceae. In: Maguire, B.; Wurdack, J.J. (Ed.). The botany of the Guayana Highland - Part III. Memoirs of the New York Botanical Garden, 10: 19-49.

Maguire, B. 1965. Rapateaceae. In: Maguire, B. (Ed.). The botany of the Guayana Highland - Part VI. Memoirs of the New York Botanical Garden, 12: 69-102.

Maguire, B. 1979. Additions to the Rapateaceae. Acta Amazonica, 9: 267-269.

Maguire, B. 1982. Rapateaceae. In: Luces de Febres, Z.; Steyermark, J.A. (Ed.) Flora de Venezuela. v. 11(2). Ediciones Fundación Educación Ambiental, Caracas, p. 85-203.

Milliken, W.; Zappi, D.C.; Sasaki, D.; Hopkins, M.; Pennington, R.T. 2010. Amazon vegetation: how much don't we know and how much does it matter? Kew Bulletin, 65: 691-709.
Pirani, J.R.; Giulietti, A.M. 1989. Flora da Serra do Cipó, Minas Gerais: Rapateaceae. Boletim de Botânica da Universidade de São Paulo, 11: 171-174.

Praia, T.S.; Gil, A.S.B.; Secco; R.S. 2016. Rapateaceae in the state of Pará, Brazil. Acta Botanica Brasilica, 30: 628-643.

Reflora Virtual Herbarium. 2017. Virtual online herbarium repository. (http://floradobrasil.jbrj.gov.br/reflora/herbarioVirtual/ ConsultaPublicoHVUC/ResultadoDaConsultaNovaConsulta. do?lingua=en). Accessed on 24/02/2017.

Rodrigues, R.S. 2015. Notes on the taxonomy and nomenclature of Monotrema bracteatum (Rapateaceae). Boletim do Museu Integrado de Roraima, 9: 19-22.

Rodrigues, R.S.; Flores, A.S. 2010. Novas ocorrências de Rapateaceae para o Brasil. Acta Botanica Brasilica, 24: 1096-1099.

Rodrigues, R.S.; Flores, A.S. 2017. A new species of Epidryos (Rapateaceae) from Guyana. Phytotaxa, 297: 197-202.

Schomburgk, R.H. 1845. Die Rapatea Friderici Augusti und SaxoFridericia regalis. Friedrich Vieweg und Sohn, Braunschweig, $14 \mathrm{p}$.

speciesLink Network. 2017. (http://www.splink.org.br/index). Accessed on 22/02/2017.

Thiers, B. 2017. Index Herbariorum: A global directory of public herbaria and associated staff. New York Botanical Garden's Virtual Herbarium (http://sweetgum.nybg.org/science/ih). Accessed on 20/02/2017.

Zappi, D.C.; Milliken, W.; Lopes, C.R.A.S.; Lucas, E.; Piva, J.H.; Frisby, S.; Biggs, N.; Forzza, R.C. 2016. Xingu State Park vascular plant survey: filling the gaps. Brazilian Journal of Botany, 39: 751-778.

Received: 07/03/17

Accepted: 13/03/17 
